\title{
A Comparative Study on Similarities Between the Definite Article 'the' and the Particle 'eun/neun' in A Novel
}

\author{
In-Young Lee ${ }^{1}$ and Mun-Koo Kang ${ }^{2 *}$ \\ ${ }^{1}$ Cheonanbakseok Elementary School, Korea \\ ${ }^{2 *}$ Corresponding Author, Kongju National University, Korea \\ ${ }^{1}$ oskhu@hanmail.net, ${ }^{2 *}$ kangmunkoo@hanmail.net
}

\begin{abstract}
The purpose of this paper is to find the meaning similarities between the two items by comparing the meaning functions of the English definite article the' and the Korean particle 'eun/neun' through the analysis of the novel. We compared the meaning functions of the English definite article 'the' with the meaning functions of the Korean search 'eun/neun' in five situations: 'anaphoric usage,' situational usage,' 'associative usage,' logical usage,' and 'usage with modifiers.' As a result, the definite article 'the' and the Korean particle 'eun/neun' were found to have similar meaning functions in these five situations.
\end{abstract}

Keywords: Definite article, Korean particle, Article usages, Meaning similarity of 'the' and 'eun/neun'

\section{Introduction}

For Korean English learners, English articles are a difficult one because there is no grammatical item called an article in Korean. In the early stages of English learning, there are many cases that Korean English learners are not even aware of the English articles. According to studies by various scholars, the perception and use of the English articles differ between English learners who have an article system in their native language and those who do not in their native language. English learners who do not have an article system in their native language tend to omit all articles from use at the beginning of English learning [1][2] [3]. Liu and Gleason conducted experiments on the use of 'the' by dividing participants into groups of Chinese, Korean, and Japanese students who don' thave the English article system and groups of users who speak Indo-European languages [4]. They found that there was a significant difference in the omission of 'the' in the 'situational usage [5]' between the two groups.

As the learner's native language has or does not have an article system, the perception of articles and difficulties in learning the articles are different. Therefore, it may be effective to use Korean as a native language for Korean learners to acquire English articles. Since the learner's native language is one of the most important factors in foreign language learning, the premise of this study is the assumption that Korean English learners will be able to learn articles more effectively if there is a Korean language item corresponding to English articles. Also, if Korean English learners learn articles through specific text contexts rather than

Article History:

Received (November 9, 2019), Review Result (December 18, 2019), Accepted (January 24, 2020) 
simply memorizing them, they will be able to understand English articles more fundamentally. For this, this study compares the situations in which the English definite article 'the' and the Korean particle 'eun/neun' are used in a novel.

\section{Method}

The purpose of this study is to compare and analyze the texts of English and Korean novels to showcase the similarities between the meaning functions of the definite article 'the' and the particle 'eun/neun.' Therefore, a comparative method was selected to compare them.

In this study, the texts used to analyze the similarities of the two items are the original English novel, 'Night Train to Lisbon (Pascal Mercier)' and 'Liseubonhaeng Yagan yeolcha' translated by Jeon, Eun-Kyung [6][7].

In Korean sentences, subject, object, adverb, etc. can be a topic by combining the particle with 'eun/neun.' Therefore, only the subject and object functions of the particle 'eun/neun' are selected within the sentence, and it is compared with the definite article 'the.' For this, we integrate and compare the non-generic usage of the definite article 'the' of scholars, and then use 'anaphoric usage,' 'situational usage,' 'associative usage,' 'logical usage' and 'usage with modifiers' as criteria for analysis.

\section{Results}

\subsection{The similarities between new and old information markers in the English articles and the Korean particles}

Thompson gives a functional explanation of the evolution of English articles [8]. It is said that the grammatical relationship such as the object or subject is fixed in the order of words, and the English articles are used to represent the old and new information. The English definite article 'the' is used to display the old information and the indefinite article ' $a(n)$ ' is used to express the new information. Therefore, the indefinite article ' $a(n)$ ' is located in front of the new nouns and the definite article 'the' is located in front of the old nouns. Similarly, in the use of Korean particles, the old information is combined with the particle 'eun/neun' and the new information is combined with the nominative case particle 'yi/ga' [9]. Huh and Kim (2014) also give an explanation of use of 'eun/neun' for old information and 'yi/ga' for new information, as in an example (1) below [10].

(1) Sagwaga iss-eoyo. Yi sagwaneun mas-iss-eoyo.

(There is an apple. The apple is delicious.)

\subsection{The meaning function of the English definite article 'the' and the Korean particles 'eun/neun'}

Throughout Christophersen, Brown, Hawkins, Quirk, Greenbaum, Leech and Svartvik, Celce-Murcia and Larsen-Freeman, the usage of the definite article 'the' was subdivided and the contents were also added [11][12][5][13][14]. The definite article 'the' has the meaning of 'definiteness' and 'identifiability' in five situations such as 'anaphoric usage,' 'situational usage,' 'associative usage,' 'logical usage,' and 'usage with modifiers.'

The Korean particle 'eun/neun' has a similar meaning to the definite article 'the.'

Lee (1981) said that 'eun/neun' is "a speaker's instruction to focus on any one item in the common consciousness of the speaker and listener [15]." 
(2) a. Dadeul wassni? (Are you all here?)

b. Ani, Yeonghuineun wassneunde Minsuneun ajig an wassda.

(No, Young-hee is here and Min-soo is not yet.)

In the speaker's question of (2a), as an answer, 'Yeonghuiga' and 'Minsuga' combined with the new information marker 'yi/ga' cannot be used. Instead, 'Yeonghuineun' and 'Minsuneun' combined are used. This is because the speaker wants to focus the listener's attention on the people named Young-hee and Min-soo in the speaker's consciousness.

Seong (1985) stated that the basic meaning of the particle 'eun/neun' is 'contrast,' and that the topic expression can be restricted because the object of the contrast must be able to experience and recognize it [16]. 'Contrast' is the selection of one of several congeners, and since the object must naturally be one of the worlds that humans can experience or recognize, the contrasting object of the combination of 'eun/neun' must be obvious in the context or predictable from the context. In the sentence (3), Lee regarded 'eun/neun' as a lexeme and referred to its meaning as 'selection,' 'exclusiveness,' 'individual [17].'

(3) (Seog-i, Hun-i, Ung-ineun mollado) Cheolsuneun bab-eul meogneunda.

(We don't know if Seok, Hun, and Woong ate or not.) Cheolsu eats rice.

The Korean particle 'eun/neun' is a 'topic marker' that serves as a device to represent the topic [18]. Regardless of other elements of the sentence, 'eun/neun' is independent and placed at the beginning of the sentence [9].

The Korean particle 'eun/neun' is a 'meaning qualifier' and has the meaning function like 'separate,' 'exclusiveness,' 'contrast,' 'distinction,' 'restrict,' 'specify,' 'separate,' 'limit [16][17][19][20][21].'

\subsection{The comparison of the meaning functions between the English definite article 'the' and the Korean particle 'eun/neun' in a novel}

We compare and analyze the meaning functions of the non-generic definite article 'the' and the particle 'eun/neun' in the five situations selected for analytical criteria in this chapter.

\subsubsection{Anaphoric Usage}

Hawkins states that the 'anaphoric usage' of the definite article 'the' is when it is used in a 'shared previous discourse set' where an object satisfying a 'descriptive predicate' exists [5]. A first noun is presented as ' $a+$ noun' and later the noun is presented as 'the + noun.' According to Quirk et al., an anaphoric reference refers to the uniqueness of the phrase 'the $\mathrm{X}$ ' given by the information previously given in the discourse [13]. An anaphoric accordance requires that the relationship between the two noun phrases be identical.

(4) I became aware with terror: he looked neglected. Not like an unwashed bum. The neglect was more inconspicuous, softer: the untended beard, little hairs growing out of his ears and nose, carelessly cut nails, a yellowish glow on the white tie, unpolished shoes [6].

(5) Hwangpyehae boineun geuui moseub-e nan kkamjjag nollassji. Geu hwangpyeham-eun ssisji anh-eun bulangjawa gat-eun geos-eun anieoss-eo. Deo misehago nun-e jal ttuiji anhneun moseub-ieossso. Sonjilhaji anh-eun suyeom, kowa gwi bakk-eulo naon teol, kkakk-eun sontob, hayan osgis-e nuleohge mud-eun ttae, dakkji anh-eun sinbal [7].

In (4) 'neglected' is first mentioned, and when it is mentioned again, it is combined with 'the (the neglect),' where 'the' is used as an anaphoric usage. In (5) 'Hwangpyehae 
(neglected)' is first mentioned, and then in 'hwangpyeham-eun (the neglect),' 'eun' is an anaphoric usage, such as the definite article 'the' used to refer to the preceding noun again.

\subsubsection{Situational Usage}

Hawkins calls this usage the 'general knowledge use' of the definite article 'the.' People who live in the same village, city, state, country, churches, pubs, theaters and public institutions can use the noun with the definite article 'the' although it is first mentioned [5].

(6) I felt like standing up and applauding. If only because of the brilliance of this daredevil speech. But the I felt: you can't applaud blasphemy, polished as it may be. No one can, least of all a priest, a man of God. And so I remained sitting. The seconds passed. It couldn't have lasted much longer, otherwise it was a catastrophe, for him as for us. Amadeu raised his head and stretched his back. [...] It was completely instinctive and illustrated, as you will see, his speech. It showed that he was his speech. Maybe that was enough to break the ice. But then something happened that seemed to everyone in the hall like a joking proof of God's existence: a dog started barking outside [6].

(7) Naneun geu daedamhan yeonseol-ui tag-wolham ttaemun-elado il-eonaseo bagsuleul chilyeogo haessso. Hajiman amuli selyeondoen munjang-ilago haedo, sin-e daehan bulgyeong-e bagsuleul bonaeseoneun an doendaneun geos-eul god kkaedal-assso. Amudo geulaeseoneun an doeeoss-eo. Sin-ui salam-in sinbuneun deodeoug an doego.... Geulaeseo geunyang anj-a iss-eossso. sigan-i heulleogassji. Sanghwang-eul geuleon sig-eulo nwadumyeon an doendaneun saeng-gag-i deul-eossso. Geugeon amade-uegena uliege daejaenan-il tenikka. amade-uneun meolileul deulgo heolileul godge pyeossso. [...] Geu haengdong-eun muuisigjeog-ieossgo, seonsaengdo ije boge doegessjiman geuui yeonseol-eul myeongbaeghage haneun geulim gat-eun geos-ieossso. Geuga god geuui yeonseol-im-eul boyeojuneun moseub.... Geugeos-eulo ginjang-eun geunyang kkaejyeoss-euljido moleuo. geuleonde geuttae, geugos-e issdeon salamdeul-ege machi sin-ui jonjaee daehan igsalseuleoun jeungmyeongcheoleom boineun il-i beol-eojyeossso. Bakkat-eseo gaega jijgi sijaghaessdeon geoyo [7].

In (6), the priest is explaining the scene of Amadeu's speech which was excellent, but there was a fraught silence because it was profane about God. In this scene, Gregorius, the listener, understands the same space and events while listening to the priest's story, so the first mentioned 'ice' is combined with the old information marker 'the.' Similarly, in (7), 'ginjang' is the first mentioned word, but it is combined with the old information marker 'eun/neun.'

\subsubsection{Associative Usage}

Hawkins suggests 'the trigger' that can be associated with the concept of 'part-of' in 'a set' shared by the speaker and listener. In a similar concept, Yule states that in the sentence of "I can give you a cup, but the handle is broken," the interlocutors share the common knowledge of "If $X$ is a cup, then $X$ will have a handle." In this case, you can combine the definite article 'the' with 'handle [5][22].'

(8) We were prepared for something, but not such a thing. From the first sentence, a breathless silence prevailed. And it became more silent and more breathless, this silence. The sentences from the pen of a seventeen-year-old iconoclast, who spoke as if he had already lived a whole life, were like whiplashes. [...] Afraid for this thin-skinned adventurer, whose vulnerability was every bit equal to his verbal force. But also afraid for us who might not be up to it. The teachers sat there very stiff, very erect. Some had shut their eyes [...] The last sentence, you'll see, [...] [6]. 
(9) Ulin imi yaggan gag-oleul hago issgin haessjiman, geu jeongdolagoneun sangsangdo mos haessso. Cheos munjang-eul deul-eun jighubuteo sum maghineun jeongjeog-i gamdolassso. Sigan-i jinalsulog jeongjeog-eun deo simhaejyeossji. Imi insaeng-eul da san deushan yeol-ilgob saljjali usang pagoejaui pen kkeut-eseo naon munjang-eun machi chaejjigjilgwado gat-assso. [...] dalbyeon mosjianhge seong-gyeogdo yeminhan i moheomgaga geogjeongdwaessso. Hajiman i il-eul gamdanghaji moshal uliga geogjeongseuleobgido haessso. Seonsaengdeul-eun mom-i ppeosppeoshage gud-eun che kkoskkoshage anj-a isseossso. myeochmyeoch-eun [...] nun-eul gamgo iss-eossso. najung-e seonsaengdo boge doegessjiman, majimag munjang-eun [...] [7].

In (8) Father Bartolomeu is explaining to Gregorius about a speech Amadeu made at school at the age of 17. Since there are the teachers in the school, 'teacher' is a noun of the new information that appears first, but combines with 'the' which indicates the old information to show 'associative usage.' In other words, 'teacher' is the first noun used in his explanation, but because of the fact that there are the teachers in the school, 'teacher' combines with the old informational marker 'the' and shows 'associative usage.' Likewise, in (9), 'Seonsaengdeul' first appears, but it is combined with the old information marker 'eun.' The definite article 'the' and the particle 'eun/neun' served as 'the trigger.' Therefore, the meaning function of 'the' and 'eun/neun' in 'associative usage' can be considered as the same.

\subsubsection{Logical Usage}

Quirk et al. explains the definite article 'the' used not because of the knowledge of the world, but because of the logical interpretation of a particular word as 'the logical use [13].' Logical usages of 'the' include ordinal numbers (first, second, etc.), superlative adjectives (best, largest, etc.), words representing an order (next, last, etc.), and uniqueness (same, only, sole, etc.).

(10) The first dream he realized; even today he stands in a white labcoat behind the counter of the shop on the Rua dos Sapateiros [6].

(11) Cheosjjae kkum-eun ilueossso. Jigeumdo huin gaun-eul ibgo sapateiluseu geolie issneun yaggug-ui panmaedaee seo iss-eunikka [7].

In (11), 'eun' of 'Cheosjjae kkum-eun' is similar in meaning function to 'the' of 'The first dream' in (10).

\subsubsection{Usage with modifiers}

The usage of 'the' used with modifiers refers to the case where the modifiers are located before or after the referent to modify it. Even if it is not familiar at the moment of utterance, the listener can find the location of the referent since these modifiers serve as a preliminary discourse. Hawkins included 'estimating relative clauses, associative clauses, NPcomplements, and nominal modifiers' as the modifiers [5].

(12) We were prepared for something, but not such a thing. From the first sentence, a breathless silence prevailed. And it became more silent and more breathless, this silence. The sentences from the pen of a seventeen-year-old iconoclast, who spoke as if he had already lived a whole life, were like whiplashes [6].

(13) Ulin imi yaggan gag-oleul hago issgin haessjiman, geu jeongdolagoneun sangsangdo mos haessso. Cheos munjang-eul deul-eun jighubuteo sum maghineun jeongjeog-i gamdolassso. Sigan-i jinalsulog jeongjeog-eun deo simhaejyeossji. Imi insaeng-eul da san deushan yeol-ilgob saljjali usang pagoejaui pen kkeut-eseo naon munjang-eun machi chaejjigjilgwado gat-assso [7]. 
In (12) 'sentences' was combined with the definite article 'the' by the definition of 'from the pen of a seventeen-year-old iconoclast.' Likewise, in (13), 'munjang' which is modified by 'yeol-ilgob saljjali usang pagoejaui pen kkeut-eseo naon' is combined with 'eun.' In this case, 'the' and 'eun/neun' have the same meaning function when used with modifiers.

\section{Conclusion}

This study examines the meaning functions of the English definite article 'the' and the Korean particle 'eun/neun' in the specific usage situations.

For this purpose, the five usages of the non-generic definite article 'the' such as 'anaphoric usage,' 'situational usage,' 'associative usage,' 'logical usage' and 'usage with modifiers' were used as analytical criteria.

As a result, the meaning functions of the English definite article 'the' and the Korean particle 'eun/neun' used in the novel were very similar under 'anaphoric usage,' 'situational usage,' 'associative usage,' 'logical usage' and 'usage with modifiers.'

\section{References}

[1] P. Master, “The English article system: acquisition, function, and pedagogy,' System, vol.25, pp.215-52, (1997) DOI: 10.1016/s0346-251x(97)00010-9

[2] B. Parrish, "A new look at methodologies in the study of article acquisition for learners of ESL," Language Learning, vol.37, pp.361-83, (1987) DOI: 10.1111/j.1467-1770.1987.tb00576.x

[3] M. Thomas, "The acquisition of English articles by first- and second-language learners," Applied Psycholinguistics, vol.10, pp.335-55, (1989) DOI: 10.1017/S0142716400008663

[4] D. Liu and J. L. Gleason, "Aquisition of the article the by non-native speakers of English: An analysis of four nongeneric uses," Studies in Second Language Acquisition, vol.24, pp.1-26, (2002) DOI: 10.1017/S0272263102001018

[5] J. A. Hawkins, "Definiteness and indefiniteness," Routledge, New York, (1978)

[6] P. Mercier, "Night train to Lisbon," Grove Press, New York, (2008)

[7] E. K. Jeon, "Liseubonhaeng Yagan yeolcha ("Night train to Lisbon”)," Doseochulpan Deulnyeok, Paju, (2017)

[8] S. A. Thompson, "Modern English from a typological point of view: Some implications of the function of word order," Linguistische Berichte, vol.54, no.1, pp.19-35, (1978)

[9] P. H. Yun, Korean semantics, Doseochulpan Yeoglag, Seoul, (2008)

[10] Y. Huh and S. J. Kim, “Contrastive Linguistics,” Doseochulpan Sotong, Anyang, (2014)

[11] P. Christophersen, "A study of their theory and use in English," Oxford University press, Copenhagen and London, (1939)

[12] R. Brown, “A first language: The early stage,” MA: Harvard University Press, (1973)

[13] R. Quirk, S. Greenbaum, G. Leech, and J. Svartvik, "A comprehensive grammar of the English language," Longman, London \& New York, (1985)

[14] M. Celce-Murcia and D. Larsen-Freeman, "The grammar book: An ESL/SEL teacher's course (2nd ed.)," MA: Heinle, Cengage Learning, Boston, (1999)

[15] K. D. Lee, "Language and consciousness," Korean language education as a foreign language, vol.6, no.1, pp.29-50, (1981)

[16] G. C. Sung, “Korean subject matter," Korean, vol.188, pp.65-90, (1985)

[17] S. K. Lee, “A study on the meaning of modern Korean particles," Seokwang Academic Archives, Seoul (1992)

[18] [H. B. Lim, “Analysis of topics and syntax in Korean,” Seoul National University Press, Seoul (2008)

[19] S. G. Kim, "The case theory of Korean,” Journal of Humanities, vol.13, pp.97-156, (1980)

[20] D. H. Jeong, “A study on particles in modern Korean,” Seokwang Academic Archives, Seoul, (1992) 
[21] W. Chae, "Meaning of Korean particle 'neun,'” Top Publisher, Seoul, (1983)

[22] G. Yule, "Explaining English grammar," Oxford University Press, Oxford, (1998) 
This page is empty by intention. 